\title{
The Flood Disaster Management Model in Wonosari Village Semarang City
}

\author{
Yuliana Rachmawati ${ }^{1}$, Kismartini $^{2}$, and Suharyanto ${ }^{2}$
}

${ }^{1}$ Environmental Science Program Postgraduate Program Diponegoro University, Semarang - Indonesia ${ }^{2}$ Department of Public Administration, Faculty of Social and Political Sciences Diponegoro University, Semarang - Indonesia ${ }^{2}$ Department of Civil Engineering, Diponegoro University, Semarang - Indonesia

\begin{abstract}
The importance of alignment in management especially in the face of disaster Floods that often occur Semarang city. This research aims to find out the Flood Disaster Management Model of wonosari village. The writer refers to the functions of management including planning, organizing, coordinating and supervising. This study was a descriptive qualitative research. Technique of collecting data used was interview, observation and document study. Technique of analyzing data used was an interactive model. Model of flood disaster management in wonosari village is preparedness, early warning, disaster mitigation, emergency response, rehabilitation and reconstruction. The planning executed was the disaster preparedness village's plan including before, during and after disaster occurrence. Meanwhile, to implement the flood disaster management, the organization was made by disaster agency. The level of integration in the disaster management is still low so it needs a strategy to improve the integration. Priority strategies that can be undertaken to improve preparedness in an integrated effort multistakeholder of watershed with administrative areas, and a clearer division of stakeholder roles in the sustainable model disaster management.
\end{abstract}

Keywords: Management; Flood disaster management; Disaster preparedness; village

\section{INTRODUCTION}

Semarang city became one of the flood subscription areas with high population and topographically Semarang City consists of hilly areas, lowland and coastal areas. These conditions make some areas have the potential flash floods, especially in areas along the banks of the Beringin River Basin. Floods in 2010 have the greatest flood characteristics especially in the wonosari kelurahan recorded 3 people drowned swept away by the flood waters that came quickly, bringing the total number of dead to 7 people.

During the rainy season, people around the Bringin basin mostly have a habit of monitoring the rainwater conditions in the river, such as that done by the people of Wonosari Village who during the rainy season comes every 10 minutes once always monitor the height of the water in the river so that when the flood comes the people are getting ready to pack household items. Wonosari urban village becomes the area affected by Flash floods due to land conversion, river sedimentation and the occurrence of extreme weather impact of climate change impact. Definition of a disaster in accordance with Law 24 of 2007 on Disaster is "event or series of events that threaten and disrupt the lives and livelihoods caused by both natural factors and/or non-natural factors and human factors that lead to the emergence of human fatalities, environmental damage, loss of property, and psychological impact" [1].
In the implementation of disaster management, so that every activities in each stage can be directed, then a specific plan is prepared at each stage the implementation of disaster management. Disaster management consists of four stages: prevention and mitigation, preparedness, response and recovery. Predisaster activities is prevention and mitigation, Eforts or activities in the context of prevention and mitigation carried out, and the aim of eliminating disasters and reducing expenditures caused by disasters. When disaster or response is a step of action or mobilization of help to help affected communities, in order to avoid increasing casualties. For example the disaster respond that must be done is flood waste management to reduce risk during. The flood waste management issues such as the generation of flood waste and infrastructure waste must be prepared [2]. so that the impact of flood waste could be minimized. The effort carried out in the rehabilitation stage is to restore the condition of the area affected by the disaster which is uncertain to a better normal condition, so that the life and livelihood of the community can run again. One of the problem in flood disaster is how to control stakeholder intention to clean up flood waste in city and area affected. There is a model to develop stakeholder intention cause by Tsunami in Banda Aceh, however, to control the stakeholder intention is still limited and very difficult to do in Semarang, especially for flood Disaster Risk Reduction in Semarang [3].

\footnotetext{
Corresponding author: yulianarachmawatiunnes@gmail.com
} 
In 2012 the activity of forecasting and flood warning system (FEWS) as a step to adaptation of climate change through flood risk readiness in Beringin watershed Semarang became an effort made by the government to cooperate through the Program of Asian Cities Climate Change Resilience Network (ACCCRN) with support from Rockefeller Foundation USA. The program has encouraged disaster risk reduction efforts in the community in Wonosari village. Based on the phenomena that have been described, it is necessary if traced a flood disaster management model in Wonosari Village.

\section{DATA AND METHODS}

This research includes the type of descriptive qualitative research that is evaluative by conducting interview techniques or direct interviews using guided interview. Source of data or information comes from data sources (key informants) who are considered to know the most about the object / social situation being examined. The source of the data in this study is:

\begin{tabular}{|l|l|c|}
\hline No & Data source & amount \\
\hline 1 & Public figure in Wonosari Villages & 2 \\
\hline 2 & $\begin{array}{l}\text { Wonosari Village Disaster } \\
\text { Preparedness Group }\end{array}$ & 4 \\
\hline 3 & Wonosari Village unit & 1 \\
\hline 5 & Disaster Agency Semarang City & 1 \\
\hline 6 & $\begin{array}{l}\text { Enviromental agency Semarang } \\
\text { City }\end{array}$ & 1 \\
\hline 7 & Public Works Service & 1 \\
\hline 8 & Non-governmental organization & 1 \\
\hline & Total & 11 \\
\hline
\end{tabular}

This data analysis technique is designed using interactive analysis model. Technique of data collecting is interview which is technique used by writer to get verbal statement through direct communication with several relevant stakeholder. In addition to interviews the author also uses the techniques of data collection and observation document review. Observations made is to make a direct observation of the object under investigation. To study a document is done by reading the documents related to the research material.

\section{RESULTS AND DISCUSSION}

\subsection{General Description Wonosari Villages}

Wonosari village is 323,549 ha. The village of Wonosari is a highland area located in western semarang. It has an altitude of 8 meters above sea level, with an area of 323,549 ha, consisting of dry land land of 31.10 ha of 155.95 ha dry land and public facilities 6,50 ha and the rest is settlement while the slope of the village wonosari $60^{\circ}$ while the average daily intensity $33^{\circ}$ Celsius.

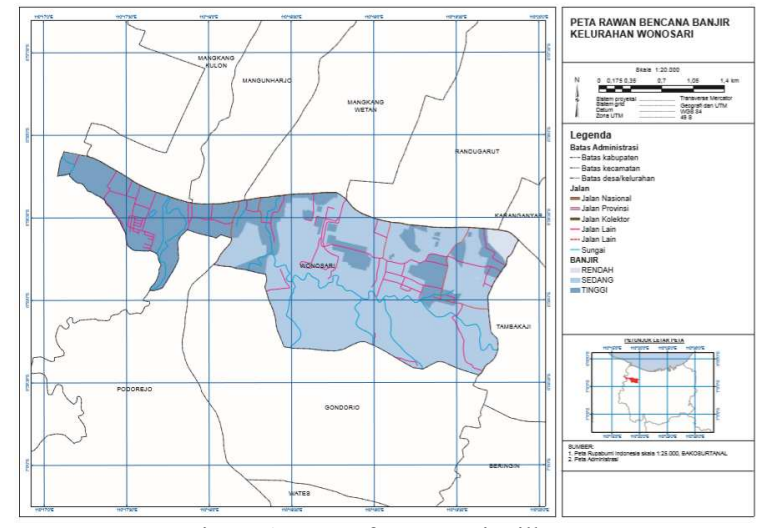

Figure 1. Map of Wonosari Villages

Wonosari Villages has a population in 2017 of 18.831 people, is the most populous village after Tambak aji and Kalipancur.

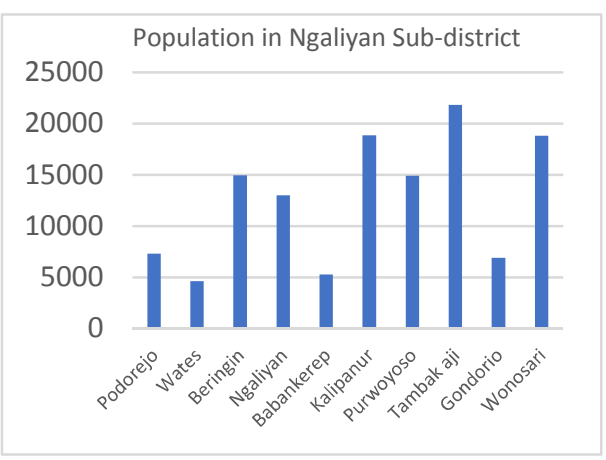

The livelihoods of residents in Wonosari Village are very diverse, ranging from entrepreneurs, civil servants / military officers, retirees, industrial workers to construction workers. However, $36 \%$ (4,956 people) of the population of Wonosari Village work in the industrial and service sectors.

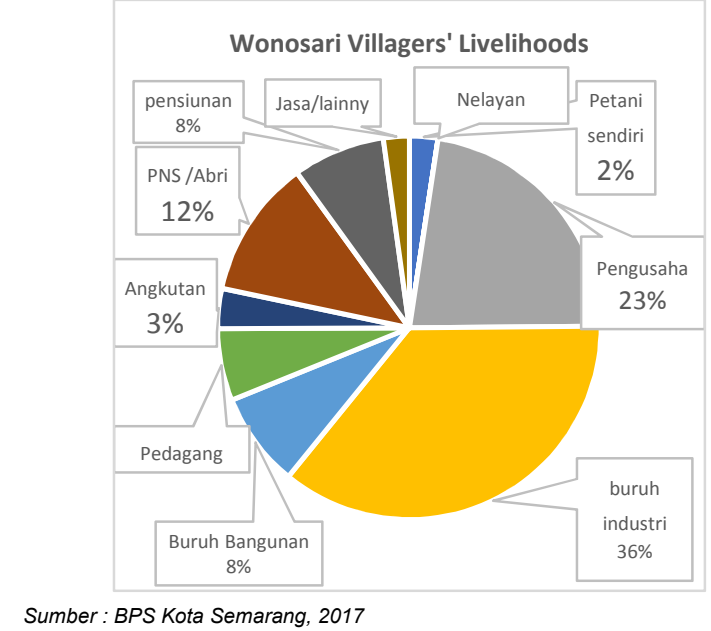

\subsection{Flood characteristics Wonosari villages}

In 1991 and 2010 there were flash floods which resulted in damage to infrastructure and material losses, even in 2010, the main road in Semarang Kendal was hampered because flash floods brought material and closed roads and caused fatalities. Wonosari is one of the villages in the Ngaliyan sub-district of Semarang 
that was affected by flooding due to runoff of the beringin river in RW 6 and 7 and the impact of plumbon river overflows in RW 2 and 3.Along the establishment of a large housing in the area over the Beringin watershed, in the mid-1990s flood began to occur during the rainy season. Flood Bringin Watershed has characteristics suddenly enlarged/elevated and occur within a short time (1-2 hours) and then recede and disappear.

\subsection{Flood Disaster management Model Wonosari villages}

The Wonosari village disaster management model which will be discussed in this chapter is management including management functions which include planning, organizing, directing and supervising. The discussion is done by analysis disaster waste management regulation in Indonesia and Semarang especially for disaster planning, organizing disaster management, coordinating among stakeholder and supervising or monitoring the implementation $[4,5,6,7]$. For detail description can be seen in the description below:

\section{1) Planning}

Flood disaster management begins with making plans to provide convenience and clarity to the relevant work units, namely handling in 3 step:

a. pre-disaster stages, Preventive actions that are included in non-structural mitigation include: Formulation of laws and regulations, Making disaster-prone maps, Making guidelines / standards / procedures, Making brochures / leaflets / posters, Research / assessment of disaster characteristics, Assessment of disaster risk analysis, Strengthening social units in the community, such as forums, Basic training disaster for the community, Mainstreaming Disaster Management in development planning, Counseling and increasing public awareness, Planning temporary shelter areas and evacuation routes in the event of a disaster. Whereas preventive measures which are included in structural mitigation are, among others, the making and placement of warning signs, hazards, prohibition to enter disasterprone areas, etc. Normalization of watersheds along the beringin watershed and improvement of drainage in the Wonosari village

b. during disasters is rapid and accurate assessment of the location, damage, loss and resources, determination of the status of disaster emergencies, rescue and evacuation of affected communities, fulfillment of basic needs, protection of vulnerable groups, immediate recovery of vital infrastructure and facilities.

c. post-disaster is improvement of the disaster area environment, improvement of public infrastructure and facilities, provision of assistance for community home improvement, psychological social recovery, health services, social, economic and cultural recovery, restoration of security and order, restoration of government functions; and restoring the function of public services as well as rebuilding infrastructure and facilities, rebuilding community social facilities, re-generating social and cultural life of the community, implementing proper design and using better equipment and disaster resilience, participation and participation of social institutions and organizations, the world business and society, improvement of social, economic and cultural conditions, improvement of public service functions, enhancement of key services in the community.

\section{2) Organizing,}

At the Kelurahan level the organizations formed are disaster preparedness groups, and disaster risk reduction forums

\section{3) Coordinating}

Coordination is needed for the division of tasks and functions between organizational units so that there is no implementation of double / overlapping tasks or tasks that are not carried out so that the desired goals can be achieved easily. The disaster management agency is a leading sector for disaster response activities

\section{4) Supervising}

Supervision by the regional secretary as well as ex officio from the head of the Semarang city disaster management agency as structurally inherent supervision, namely from the mayor to the structure below. Supervision is carried out through reports that are submitted to the Mayor.

Wonosari Village is one of the areas that has developed a community-based disaster management model. Understanding of disaster management helps transform communities to adapt, recognize risks and live in harmony with disasters. Stages of transformation from one community to another, but community-based disaster risk reduction processes and requirements such as:

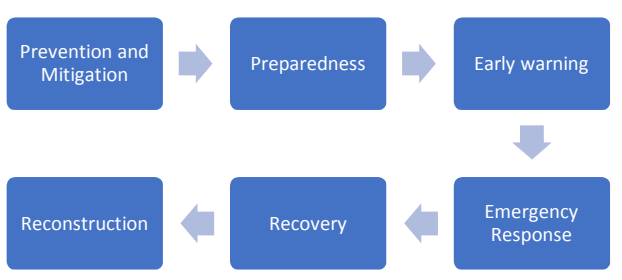




\section{CONCLUSION}

This study aims to determine the flood disaster management model in Wonosari villages Semarang city. The following are the results obtained in this study: 1). Planning carried out is a village disaster preparedness plan including before, during, and after a disaster.

2). Meanwhile, to implement flood disaster management, the organization was created by a disaster agency.

$3)$. The level of integration in disaster management is still low so a strategy is needed to improve integration. 4). Priority strategies that can be applied to improve preparedness in integrated integrated efforts of watersheds with administrative regions, and the division of clearer stakeholder roles in sustainable disaster management models

\section{REFERENCES}

1. Indonesia Government, Indonesia Law No.24 year 2007, Disaster Management. (2007).

2. Nakayama, H, Shimaoka, T, Omine, K, Maryono, Patsaraporn, P, Siriratpiriya, O., Solid Waste
Management in Bangkok at 2011 Thailand Floods, Journal of Disaster Research (8).3, pp.456-464 (2013).

3. Maryono, Nakayama, H, Shimaoka, T, Identification of factors affecting stakeholders intentions to promote preparedness in disaster waste management: A structural equation modeling approach. Memoirs of Faculty Engiengeeing Kyushu University, 74(3), 79-98, (2015).

4. National Disaster Management Board, Disaster Management Guide line, Head of National Disaster Management Board regulation number 4 year 2008.

5. GOI-UNDP. Good Practices in Community Based Disaster Risk Management, Gender Mainstreaming Chapter. 2009.

6. Mercy Corps.. Established Community Based Early Warning System: Practicioner's Handbook. Nepal: Mind Share Communications Pvt. Ltd. 2010

7. National Government, Disaster Management Operation, National Government Regulation Number 21 year 2008. 